\title{
Peran Kinerja Pelayanan pada Pengaruh Investasi, Biaya Operasional Kinerja Keuangan terhadap Pendapatan
}

\author{
${ }^{1}$ Petrus Kondoallo, ${ }^{2 J M V ~ M u l y a d i ~}$ \\ 12Universitas Pancasila, Indonesia
}

\section{N F O A R T I K E L}

\author{
JEL Classification: \\ M40 \\ $\mathrm{H} 20$
}

Keywords:

Services Performance and Revenue

\begin{abstract}
$A B S T R A C T$
This study examines the role of service performance on the effect of Investment, Operational Costs and Financial Performance on the Income of BLU hospitals, the sample consisted of eighteen hospitals with multiple linear regression analysis techniques. The classic assumption test results show that the model tested is normally distributed, there is no multicollinarity and there is no heterokedacity and the autocorrelation model does not occur. Testing is done with two test models, namely the first test of the effect of investment, operational costs and financial performance on service performance which results simultaneously all dependent variables influence the independent variable while only financial performance partially influences the service performance while investment and influential operational costs do not significant, then the second test partially shows that operational costs and service performance have a significant effect on income, this study also uses path analysis where the results show indirectly investment and financial performance through service performance has a significant influence on income.
\end{abstract}

\begin{abstract}
A B S T R A K
Penelitian ini menguji peran kinerja pelayanan pada pengaruh Investasi, Biaya Operasional dan Kinerja Keuangan terhadap PendapatanRumah Sakit BLU, sampel terdiri delapan belas Rumah Sakit dengan teknik analisis regresi linier berganda. Hasil uji asumsi klasik menunjukkan model yang diuji berdistribusi normal, tidak terdapat multikolienaritas dan tidak terjadi heteroskedastisitas serta model regresi tidak terjadi autokorelasi. Pengujian dilakukan dengan dua model pengujian yaitu pengujian pertama Pengaruh Investasi, Biaya Operasional dan Kinerja Keuangan terhadap Kinerja Pelayanan yang hasilnya secara simultan seluruh variabel dependen berpengaruh terhadap variabel independen sedangkan secara parsial hanya Kinerja Keuangan yang berpengaruh signifikan terhadap Kinerja Pelayanan sementara Investasi dan Biaya Operasional berpengaruh tidak signifikan, kemudian pengujian kedua secara parsial menunjukkan Biaya Operasional dan Kinerja Pelayanan berpengaruh signifikan terhadap Pendapatan. Penelitian ini juga menggunakan analisis jalur yang hasilnya menunjukkan secara tidak langsung Investasi dan Kinerja Keuangan melalui Kinerja Pelayanan mempunyai pengaruh signifikan terhadap Pendapatan.
\end{abstract}

\section{Pendahuluan}

Peraturan Pemerintah Nomor 23 Tahun 2005 tentang Pengelolaan Keuangan Badan Layanan Umum pada pasal 2 disampaikan bahwa BLU bertujuan untuk meningkatkan pelayanan kepada masyarakat dalam rangka memajukan kesejahteraan umum dan mencerdaskan kehidupan bangsa dengan memberikan fleksibilitas dalam pengelolaan keuangan berdasarkan prinsip ekonomi, produktivitas dan penerapan praktekbisnis yang sehat. Dengan banyaknya Rumah Sakit berstatus sebagai Badan Layanan Umum diharapkan pelayanan kesehatan kepada masyarakat akan semakin baik dan dengan fleksibilitas pengelolaan keuangan yang telah diberikan maka Rumah Sakit dapat mengembangkan sumber daya yang ada untuk meningkatkan pendapatannya.

Menurut Yuliani (2014) dalam penelitiannya menyampaikan bahwa penerimaan Rumah Sakit menjadi sumber pembiayaan utama bagi Rumah Sakit, dan menjadi hal yang sangat penting dalam

${ }^{*}$ Email Korespondensi: ${ }^{1}$ petruskondoallo@yahoo.co.id ${ }^{2}$ mulyadijmv@gmail.com 
pengelolaan operasional Rumah Sakit dan pendapatan Rumah Sakit harus sesuai dengan apa yang telah dianggarkan, karena jika target penerimaan atau pendapatan dalam anggaran Rumah Sakit tidak terpenuhi maka kinerja operasional Rumah Sakit dapat terganggu.

Pertambahan pendapatan RS BLU pertahunnya menunjukkan fluktuatif dan ada beberapa Rumah Sakit cenderung mengalami penurunan, berikut dibawah ini tabel pertambahan pendapatan RS BLU beberapa tahun:

Tabel 1

Pertumbuhan Pendapatan BLU

\begin{tabular}{|c|c|c|c|c|c|}
\hline \multirow{2}{*}{ No } & \multirow{2}{*}{ Daftar RS } & \multicolumn{4}{|c|}{ Pertambahan Pendapatan BLU } \\
\hline & & 2010 & 2011 & 2012 & 2013 \\
\hline 1 & RSUPF & 88.067 .701 .849 & 59.790 .993 .875 & 55.410 .974 .952 & $(2.945 .147 .172$ \\
\hline 2 & RSUPS & 23.447 .000 .668 & 67.309 .794 .453 & 51.365 .312 .567 & 85.355 .933 .007 \\
\hline 3 & RSUPP & 2.480 .197 .786 & 27.382 .063 .659 & 14.066 .196 .583 & 33.847 .186 .195 \\
\hline 4 & RSDP & 8.196 .259 .125 & 32.413 .628 .367 & 63.065 .187 .251 & (33.475.792.128 \\
\hline 5 & RSAM & 157.844 .091 .087 & 40.931 .597 .875 & 64.674 .571 .809 & 238.641 .529 .903 \\
\hline 6 & RSMHP & 104.712 .442 .776 & 68.159 .515 .554 & 25.357 .431 .645 & 13.844 .446 .780 \\
\hline 7 & RSSB & 96.780 .707 .503 & 46.411 .169 .340 & 329.732 .315 & 41.229 .597 .378 \\
\hline 8 & RSMC & $(14.897 .344 .681)$ & 20.017 .176 .734 & 19.918.597.168 & 8.150 .307 .343 \\
\hline 9 & RSOS & 12.268 .613 .170 & 6.033.273.716 & 7.925 .466 .480 & 43.600 .567 .310 \\
\hline 10 & RSJH & 148.702 .305 .528 & $(54.377 .375 .448)$ & 93.140 .436 .589 & 50.094 .188 .818 \\
\hline 11 & RSABH & 6.406 .217 .000 & 4.899.639.000 & 13.069 .156 .000 & 10.766 .011 .088 \\
\hline 12 & RSPRB & 8.156 .098 .213 & 1.861 .560 .175 & 1.070 .774 .014 & 5.601 .971 .280 \\
\hline 13 & RSJSH & (1.616.601.498) & 429.554 .109 & 4.030 .359 .822 & 11.873 .128 .639 \\
\hline 14 & RSPI & 12.989 .860 .565 & 2.816 .626 .068 & 5.094 .746 .719 & 6.671 .779 .095 \\
\hline 15 & RSJSM & $(11.568 .033 .540)$ & 1.808 .299 .040 & 4.941.815.604 & 19.953 .395 .633 \\
\hline 16 & RSNB & 8.154 .766 .384 & & 12.542 .386 .507 & 5.638 .749 .742 \\
\hline 17 & RSKS & 6.234 .751 .514 & 4.479 .520 .255 & 2.362 .574 .872 & 21.045 .196 .353 \\
\hline 18 & RSMM & 4.191 .990 .437 & $(24.453 .935 .456)$ & 16.328 .002 .405 & 20.592 .028 .783 \\
\hline
\end{tabular}

Trend pada tabel 1 bukanlah kondisi yang diinginkan oleh Rumah Sakit BLU karena setiap Rumah Sakit tentunya sudah memiliki target pendapatan yang harus dicapai yang tertuang dalam Renstra atau RSB (Rencana Starategis Bisnis) yang disusun untuk rencana kerja selama 5 (lima) tahun kedepan dan RAB (Rencana Anggaran Bisnis) yang disusun setiap tahun, target pendapatan yang disusun oleh Rumah Sakit telah diperhitungkan dengan baik dengan harapan bahwa pendapatan dan pertambahan pendapatan Rumah Sakit akan terus mengalami peningkatan dengan dipengaruhi pertambahan investasi, biaya operasional dan peningkatan pelayanan kesehatan kepada masyarakat, sehingga kondisi pada tabel diatas yaitu pertumbuhan pendapatan dalam kurun waktu 4 (empat) tahun dari tahun 2010 sampai dengan 2013 diperkirakan tidak sesuai dengan perencanaan atau target yang telah disusun oleh Rumah Sakit.

Menurut Zaenab (2013) dalam penelitiannya bahwa peningkatan pendapatan dipengaruhi oleh empat variabel yaitu Investasi, Tenaga Kerja,
Inflasi dan Produk Domestik Regional Bruto dalam kondisi baik.

Permana (2015) dalam penelitiannya menyatakan bahwa biaya operasional berpengaruh positif dan signifikan terhadap pendapatan.

Dengan membandingkan hasil dari beberapa penelitian dengan kondisi pertambahan pendapatan Rumah Sakit BLU maka timbul pertanyaan Seberapa besar biaya operasional yang telah dikeluarkan oleh Rumah Sakit dan investasi yang sudah dilakukan oleh Rumah Sakituntuk meningkatkan pendapatan? Apakah biaya operasional dan investasi Rumah Sakit telah memberikan pengaruh yang positif terhadap pertambahan pendapatan Rumah Sakit? Dan Apakah pertambahan pendapatan yang pada tahun 2010 sampai dengan tahun 2013 sudah sesuai dengan yang diinginkan oleh Rumah Sakit?

Pendapatan Rumah Sakit selain dapat dipengaruhi oleh Investasi, Tenaga Kerja, Inflasi dan Biaya Operasional juga dapat dipengaruhi oleh Kualitas Pelayanan, hal tersebut dibuktikan oleh Pakki (2016) dan Safitri (2015) dalam penelitiannya menunjukkan adanya pengaruh positif dan signifikan dari variabel kualitas pelayanan terhadap income Rumah Sakit. Kemudian pendapatan dapat dipengaruhi juga oleh Kinerja Keuangan, kinerja keuangan dapat diukur atau dihitung menggunakan rasio-rasio keuangan yang digunakan oleh Rumah Sakit. Hal ini dibuktikan oleh hasil penelitian dari Istiara (2015) yang menunjukkan hasil uji korelasi bahwa Perputaran Aktiva Tetap mempunyai hubungan yang cukup kuat terhadap profitabilitas.

Kualitas pelayanan pada Rumah Sakit BLU pada umumnya berkaitan dengan kinerja (prestasi kerja) yaitu hasil kerja yang diberikan secara kualitas dan kuantitas yang dicapai oleh suatu Rumah Sakitdalam melaksanakan tugas dan fungsinya dalam memberikan pelayanan kepada masyarakat.Kinerja Rumah Sakit BLU terdiri dari kinerja pelayanan dan kinerja keuangan, untuk mengukur atau menilai kinerja Rumah SakitBLU dapat menggunakan sistem penilaian yang sudah dibuat oleh Kementerian Keuangan melalui Peraturan Dirjen Perbendaharaan Nomor 36 Tahun 2016 tentang Pedoman Penilaian Kinerja BLU Bidang Layanan Kesehatan.

Bahwa perlu disampaikan juga beberapa penelitian yang menyatakan hal yang berbeda yaitu diantaranya Ririn (2014) dalam penelitiannya menunjukkan hasil bahwa secara parsial belanja modal terhadap PAD tidak berpengaruh 
signifikan, artinya investasi tidak memberikan pengaruh terhadap pendapatan kemudian Rosmalia (2014) dalam penelitiannya menunjukkan hasil bahwa investasi berpengaruh tidak signifikan terhadap PDRB dan PAD.

Dengan seluruh data dan informasi yang sudah disampaikan maka dapat dikatakan bahwa adanya keterkaitan antara Biaya Operasional, Investasi, Kinerja Keuangan dan Kinerja Pelayanan dengan Pendapatan Rumah Sakit tetapi perlu diketahui apakah variabel Biaya Operasional, Investasi, Kinerja Keuangan dan Kinerja Pelayanan pada Rumah Sakit BLUmemberikan pengaruh terhadap pendapatan Rumah Sakit.

\section{Telaah Teori dan Pengembangan Hipotesis}

Sesuai dengan Undang-Undang RI Nomor 44 Tahun 2009 tentang Rumah Sakit pada pasal 29 ayat 1 huruf $b$ dan g disampaikan bahwa Rumah Sakit wajib memberikan pelayanan kesehatan yang aman, bermutu, antidiskriminasi dan efektif dengan mengutamakan kepentingan pasien sesuai dengan standar pelayanan Rumah Sakit dan Rumah Sakit memiliki kewajiban membuat, melaksanakan dan menjaga standar mutu pelayanan kesehatan di Rumah Sakit sebagai acuan melayani pasien. Sedangkan pada pasal 30 ayat 1 huruf $b$ disampaikan bahwa setiap Rumah Sakit mempunyai hak untuk menerima imbalan jasa pelayanan serta menentukan remunerasi, insentif dan penghargaan sesuai dengan peraturan perundang-undangan, berdasarkan amanat undang-undang tersebut maka Rumah Sakit perlu melakukan investasi yang tepat, pembiayaan kegiatan operasionalnya yang efektif dan efisien, meningkatkan pengelolaan keuangan dan meningkatkan kinerja pelayanan agar Rumah Sakit dapat memberikan pelayanan kesehatan yang aman, bermutu, efektif dan dapat menjaga standar mutu pelayanan kesehatan sehingga pada akhirnya Rumah Sakit dapat meningkatkan pendapatan operasionalnya.

Berdasarkan kondisi tersebut diatas maka menarik untuk mengetahui :

\section{Pengaruh Investasi terhadap Pendapatan Rumah Sakit BLU}

Menurut Abdul Halim (2008:5) bahwa setiap pengadaan atau pembelian aset yang bermanfaat lebih dari 12 (dua belas) bulan kemudian aset tersebut digunakan dalam kegiatan pemerintahan yang bermanfaat baik secara ekonomis, sosial dan atau manfaat lainnya yang dapat meningkatkan kemampuan pemerintah dalam melayani masyarakat adalah merupakan suatu kegiatan investasi. Menurut Anggara (2016 : 236) bahwa belanja modal digunakan untuk menampung seluruh pengeluaran negara yang dialokasikan untuk pembelian barang-barang kebutuhan investasi (dalam bentuk aset tetap dan aset lainnya).

Investasi yang dilakukan oleh Rumah Sakit dalam bentuk aset tetap dan aset lainnya yang pengadaannya menggunakan anggaran belanja modal, diharapkan dapat memberikan pengaruh terhadap pendapatan hal ini sesuai dengan penelitian yang dilakukan oleh Zaenab (2013) memberikan hasil bahwa peningkatan pendapatan disalah satu Rumah Sakit pemerintah di Surabaya dipengaruhi oleh empat variabel yaitu investasi, tenaga kerja, inflasi dan produk domestik regional bruto dalam kondisi baik.

\section{Pengaruh Biaya Operasional terhadap Pendapatan Rumah Sakit BLU}

Biaya operasional menurut Peraturan Direktur Jenderal Perbendaharaan Nomor Per36/PB/2016 tentang Pedoman Penilaian Kinerja Badan Layanan Umum Bidang Layanan Kesehatan merupakan seluruh biaya yang dibutuhkan dalam memberikan pelayanan kepada masyarakat, yang terdiri dari belanja pegawai dan belanja barang yang sumber dananya berasal dari penerimaan anggaran APBN dan pendapatan PNBP BLU.

Berdasarkan PMK Nomor 76 Tahun 2008 biaya BLU diklasifikasikan menjadi beberapa jenis biaya yaitu :

1. Biaya Layanan merupakan seluruh biaya yang terkait langsung dengan pelayanan kepada masyarakat yang meliputi: biaya pegawai, bahan, jasa layanan, pemeliharaan, daya dan jasa, dan biaya langsung lainnya.

2. Biaya Umum dan Administrasi merupakan biaya-biaya yang diperlukan untuk administrasi dan biaya yang bersifat umum dan tidak terkait secara langsung dengan kegiatan pelayanan BLU. Biaya ini meliputi biaya pegawai, administrasi perkantoran, pemeliharaan, langganan daya dan jasa, dan biaya promosi.

3. Biaya Lainnya merupakan biaya yang tidak dapat dikelompokan ke dalam biaya layanan dan biaya umum dan administrasi. Biaya ini antara lain meliputi biaya bunga dan biaya administrasi bank.

Menurut Suyanto (2018) biaya didefinisikan sebagai sumber daya yang dikorbankan untuk 
mencapai tujuan tertentu, pengorbanan ini biasanya diukur sebagai jumlah moneter yang merupakan beban-beban (expenses) untuk mendapatkan barang atau jasa.

Biaya-biaya yang dikeluarkan oleh Rumah Sakit tentunya memiliki tujuan tertentu yaitu untuk dapat memberikan pengaruh terhadap peningkatan pendapatan melalui peningkatan pelayanan kesehatan kepada masyarakat. Permana (2015) dalam penelitiannya memberikan hasil bahwa Biaya Operasional berpengaruh positif dan signifikan terhadap Pendapatan Hotel Banjarmasin International.

\section{Pengaruh Kinerja Keuangan terhadap Pendapatan Rumah Sakit BLU}

Kinerja keuangan merupakan suatu analisis untuk menilai sejauh mana suatu perusahaan telah melaksanakan aktivitas sesuai aturan-aturan pelaksanaan keuangan. Gambaran tentang keberhasilan Rumah Sakit yang telah dicapai akibat berbagai aktivitas yang telah dilakukan dapat dilihat dari hasil penilaian kinerja salah satunya adalah penilaian terhadap kinerja keuangannya dan semestinya kinerja keuangan dapat memberikan pengaruh terhadap pendapatan Rumah Sakit, sebagaimana telah dibuktikan beberapa penelitian bahwa kinerja keuangan mempengaruhi pertumbuhan laba, pendapatan saham dan laba perusahaan yaitu diantaranya Hamindu (2013) dalam penelitiannya memberikan hasil bahwa kinerja keuangan secara parsial berpengaruh signifikan terhadap pertumbuhan laba. Supriyanto (2018) dan Supriyanto (2015) dalam penelitiannya memberikan hasil bahwa kinerja keuangan secara simultan berpengaruh signifikan terhadap pendapatan saham perbankan. Nurpitasari (2018) dalam penelitiannya memberikan hasil bahwa kinerja keuangan berpengaruh positif dan signifikan terhadap laba perusahaan.

\section{Pengaruh Kinerja Pelayanan terhadap Pendapatan Rumah Sakit BLU}

Kualitas pelayanan pada Rumah Sakit BLU pada umumnya berkaitan dengan kinerja (prestasi kerja) yaitu hasil kerja yang diberikan secara kualitas dan kuantitas yang dicapai oleh suatu Rumah Sakit dalam melaksanakan tugas dan fungsinya dalam memberikan pelayanan kepada masyarakat, walaupun Rumah Sakit BLU tidak berorientasi kepada profit tetapi menurut UndangUndang Nomor 44 Tahun 2009 tentang Rumah Sakit pada pasal 30 ayat $1 \mathrm{~b}$ menjelaskan bahwa
Rumah Sakit berhak untuk menerima imbalan jasa pelayanan dari pelayanan yang diberikan kepada masyarakat dan sesuai dengan Peraturan Pemerintah Nomor 23 Tahun 2005 tentang Pengelolaan Keuangan Badan Layanan Umum pada pasal 14 ayat 2 dijelaskan bahwa imbalan atas jasa layanan yang diterima oleh BLU dari masyarakat diakui sebagai pendapatan operasional BLU.

Berdasarkan amanat undang-undang dan peraturan pemerintah tersebut maka Rumah Sakit BLU berusaha meningkatkan kualitas atau kinerja pelayanannya agar pendapatan operasional Rumah Sakit dapat meningkat, berikut dibawah ini beberapa penelitian yang menunjukan pengaruh kualitas pelayanan terhadap pendapatan Rumah Sakit : Paki (2016) dalam penelitian dapat disimpulkan adanya pengaruh positif dan signifikan dari variabel Kualitas Pelayanan terhadap Income Rumah Sakit; Fitriani (2014) dalam penelitiannya memberikan hasil bahwa Kualitas Pelayanan mempunyai pengaruh terhadap Loyalitas Pasien, Kualitas Pelayanan mempunyai pengaruh terhadap Kepuasan Pasien, Kepuasan Pasien mempunyai pengaruh terhadap Loyalitas Pasien dan Kualitas Pelayanan mempunyai pengaruh tidak langsung terhadap Loyalitas Pasien melalui Kepuasan Pasien; Handayani (2010) dalam penelitiannya memberikan hasil bahwa Kualitas Pelayanan berpengaruh terhadap Kepuasan Pasien dan Kepuasan Pasien berpengaruh terhadap Minat Beli Pasien Rawat Inap.

Pengaruh Biaya Operasional, Investasi dan Kinerja Keuangan terhadap Kinerja Pelayanan Rumah Sakit

Pelayanan merupakan hal utama dan yang terpenting dalam kegiatan Rumah Sakit hal ini sesuai dengan yang diamanatkan oleh UndangUndang Nomor 44 Tahun 2009 Tentang Rumah Sakit pada pasal 4 menjelaskan bahwa Rumah Sakit mempunyai tugas memberikan pelayanan kesehatan perorangan secara paripurna kemudian pada pasal 5 menjelaskan bahwa Rumah Sakit mempunyai fungsi, yaitu Penyelengaraan pelayanan pengobatan dan pemulihan kesehatan sesuai dengan standar pelayanan Rumah Sakit, Pemeliharaan dan peningkatan kesehatan perorangan melalui kesehatan yang paripurna tingkat kedua dan ketiga sesuai dengan kebutuhan medis, Penyelenggaraan pendidikan dan pelatihan sumber daya manusia dalam rangka peningkatan kemampuan dalam pemberian pelayanan 
kesehatan danPenyelenggaraan penelitian dan pengembangan serta penapisan teknologi bidang kesehatan dalam rangka peningkatan pelayanan kesehatan dengan memperhatikan etika ilmu pengetahuan bidang kesehatan.

Berdasarkan amanat undang-undang tersebut maka kinerja pelayanan menjadi perhatian khusus yang diharapkan mengalami peningkatan sehingga memberikan pengaruh terhadap kepuasan masyarakat dan diharapkan juga berpengaruh terhadap jumlah kunjungan yang pada akhirnya dapat meningkatkan pendapatan Rumah Sakit. Berikut dibawah ini hasil penelitian mengenai pengaruh pelayanan terhadap kepuasaan dan loyalitas pasien.

Handayani (2010) dalam penelitiannya memberikan hasil bahwa Kualitas Pelayanan Berpengaruh terhadap Kepuasan Pasien dan Kepuasan Pasien berpengaruh terhadap Minat Beli Pasien Rawat Inap.Fitriani (2014) dalam penelitiannya memberikan hasil bahwa Kualitas Pelayanan mempunyai pengaruh terhadap Loyalitas Pasien, Kualitas Pelayanan mempunyai pengaruh terhadap Kepuasan Pasien, Kepuasan Pasien mempunyai pengaruh terhadap Loyalitas Pasien dan Kualitas Pelayanan mempunyai pengaruh tidak langsung terhadap Loyalitas Pasien melalui Kepuasan Pasien.

Berdasarkan beberapa pemikiran diatas maka yang perlu menjadi perhatian bagi manajemen Rumah Sakit adalah mengetahui Pengaruh Investasi, Biaya Operasional, Kinerja Keuangan terhadap Pendapatan dengan Kinerja Pelayanan sebagai variabel intervening. Berikut dibawah ini model kerangka pemikiran dalam bentuk gambar :

\section{Gambar 1 \\ Kerangka Pemikiran Penelitian}

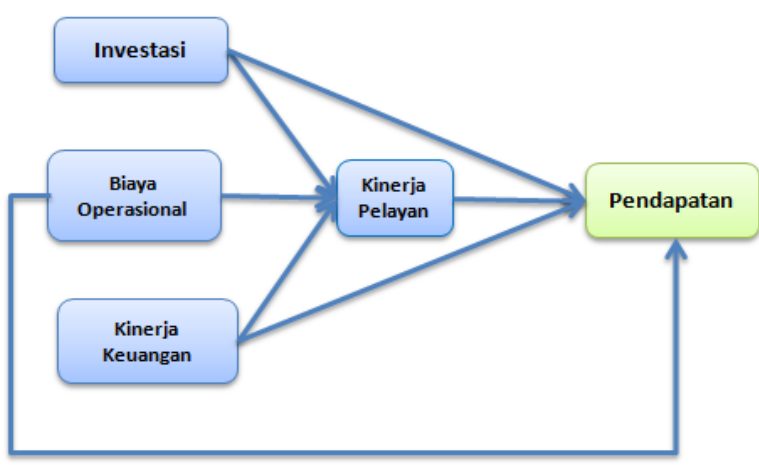

$\mathrm{H}_{1}$ : Investasi Rumah Sakit BLU berpengaruh signifikan terhadap Kinerja Pelayanan
$\mathrm{H}_{2}$ : Biaya Operasional Rumah Sakit BLU berpengaruh signifikan terhadap Kinerja Pelayanan

$\mathrm{H}_{3}$ : Kinerja Keuangan Rumah Sakit BLU berpengaruh signifikan terhadap Kinerja Pelayanan

$\mathrm{H}_{4}$ : Investasi Rumah Sakit BLU berpengaruh signifikan terhadap Pendapatan

$\mathrm{H}_{5}$ : Biaya Operasional Rumah Sakit BLU berpengaruh signifikan terhadap Pendapatan

$\mathrm{H}_{6}$ : Kinerja Keuangan Rumah Sakit BLU berpengaruh signifikan terhadap Pendapatan

$\mathrm{H}_{7}$ : Kinerja Pelayanan Rumah Sakit BLU berpengaruh signifikan terhadap Pendapatan

$\mathrm{H}_{8}$ : InvestasiRumah Sakit BLU melalui Kinerja Pelayanan berpengaruh signifikan terhadap Pendapatan

$\mathrm{H}_{9}$ : Biaya OperasionalRumah Sakit BLU melalui Kinerja Pelayanan berpengaruh signifikan terhadap Pendapatan

$\mathrm{H}_{10}$ : Kinerja KeuanganRumah Sakit BLU melalui Kinerja Pelayanan berpengaruh signifikan terhadap Pendapatan.

\section{Metode Penelitian}

Populasi yang ditetapkan dalam penelian ini adalah seluruh Rumah Sakit berstatus badan layanan umum dibawah Kementerian Kesehatan yang laporan keuangannya telah dipublikasikan oleh Kementerian Keuangan sebagai bagian dari Laporan Keuangan Pemerintah Pusat untuk periode tahun 2010 sampai dengan tahun 2013sebanyak 31 (tiga puluh satu) Rumah Sakit BLU. Dikarenakan keterbatasan data dan informasi yang dapat diperoleh maka dari populasi Rumah Sakit BLU sebanyak 31 (tiga puluh satu) hanya 18 (delapan belas) Rumah Sakit BLU yang dapat dijadikan sampel dalam penelitian ini.

Teknik yang digunakan untuk mengumpulkan data dalam penelitian ini adalah dokumentasi, yaitu dengan cara mengumpulkan, mencatat, dan mengkaji data sekunder yang berupa laporan keuangan Rumah Sakit BLU yang telah dipublikasikan oleh Kementerian Keuangan melalui situs resmi yaitu www.kemenkeu.go.id

Variabel yang digunakan dalam penelitian ini adalah Investasi (I), Biaya Operasional (BO), Kinerja Keuangan (KU) sebagai variabel independen, sedangkan Pendapatan Rumah Sakit BLU sebagai variabel dependen dan Kinerja 
Pelayanan (KP) sebagai variabel intervening. Data yang digunakan dalam penelitian ini berjenis data kuantitatif.

\section{Investasi}

Investasi merupakan pemanfatan dana yang tersedia untuk pembelian barang-barang yang dipergunakan untuk memperoleh pendapatan dimasa mendatang. Variabel investasi dalam penelitian ini adalah investasi yang dilakukan oleh Rumah Sakit BLU dalam bentuk aset tetap yang terdiri dari Tanah, Peralatan dan Mesin, Gedung dan Bangunan, Jalan, Irigasi dan Jaringan, Aset Tetap Lainnya.

Variabel ini diukur dari jumlah nilai investasi atau aset tetap yang pada laporan keuangan pada tahun tertentu dengan skala pengukurannya adalah rasio.

\section{Biaya Operasional}

Biaya operasional merupakan seluruh biaya yang dibutuhkan dalam memberikan pelayanan kepada masyarakat yang terdiri dari belanja pegawai dan belanja barang dan sumber dananya berasal dari penerimaan anggaran APBN dan Pendapatan PNBP BLU. Variabel biaya operasional dalam penelitian ini adalah biayabiaya yang dikeluarkan oleh Rumah Sakit BLU untuk membiayai kegiatan operasional yang mempergunakan anggaran belanja pegawai dan anggaran belanja barang yang bersumber dananya dari APBN dan Pendapatan PBNP BLU. Biaya operasional Rumah SakitBLU dapat dibagi menjadi beberapa jenis, yaitu Biaya layanan, Biaya Umum dan Administrasi, dan Biaya Lainnya.

Variabel ini diukur dari jumlah nilai biaya administrasi dan pelayanan yang tercatat pada laporan keuangan pada tahun tertentu dengan skala pengukurannya adalah rasio.

\section{Kinerja Keuangan}

Kinerja keuangan adalah suatu usaha formal yang dilaksanakan perusahaan untuk mengevaluasi efisien dan efektivitas dari aktivitas perusahaan yang telah dilaksanakan pada periode waktu tertentu. Variabel kinerja keuangan dalam penelitian adalah hasil perhitungan rasio keuangan yang dilakukan oleh manajemen Rumah Sakit BLU dengan menggunakan pedoman yang sudah diatur oleh kementerian keuangan melalui Peraturan Direktur Jenderal Perbendaharaan Nomor 36 tahun 2016. Variabel ini diukur dari jumlah nilai investasi atau aset tetap yang dilaporkan pada tahun tertentu dengan skala pengukurannya adalah rasio.

\section{Kinerja Pelayanan}

Kualitas pelayanan pada Rumah Sakit BLU pada umumnya berkaitan dengan kinerja (prestasi kerja) yaitu hasil kerja yang diberikan secara kualitas dan kuantitas yang dicapai oleh suatu Rumah Sakit dalam melaksanakan tugas dan fungsinya dalam memberikan pelayanan kepada masyarakat. Variabel kinerja pelayanan dalam penelitian adalah hasil perhitungan dan penilaian beberapa kegiatan pelayanan yang dilakukan oleh manajemen Rumah Sakit BLU dengan menggunakan pedoman yang sudah diatur oleh Kementerian Keuangan melalui Peraturan Direktur Jenderal Perbendaharaan Nomor 36 Tahun 2016.

Variabel ini diukur dari hasil perhitungan penilaian kinerja yang sudah ditetapkan yang dilaporkan pada tahun tertentu dengan skala pengukurannya adalah rasio.

\section{Pendapatan}

Sesuai dengan Peraturan Menteri Keuangan Nomor 220 Tahun 2016 disampaikan bahwa pendapatan badan layanan umum adalah arus masuk bruto dari manfaat ekonomi yang timbul dari aktivitas BLU selama satu periode yang mengakibatkan penambahan ekuitas bersih. Pendapatan BLU sebagai bagian dari keuangan negara yang merupakan kelompok pendapatan negara bukan pajak. Variabel Pendapatan dalam penelitian ini adalah pendapatan yang diterima oleh Rumah Sakit dari pelayanan kesehatan kepada pasien dan pendapatan selain dari pelayanan kesehatan.

Variabel ini diukur jumlah pendapatan yang terdapat pada laporan operasional tahun tertentu dengan skala pengukuran adalah rasio.

\section{Pengujian Asumsi Klasik}

Untuk mendapatkan hasil pengujian yang baik, maka semua data dalam penelitian ini harus diuji terlebih dahulu agar tidak melanggar asumsi klasik yang disyaratkan yaitu diantaranyaUji Normalitas, Uji Multikolinearitas, Uji Autokorelasi, Uji Heteroskedastisitas.

\section{Pengujian Hipotesis}

Pengujian hipotesis dilakukan untuk mengetahui pengaruh antara satu atau beberapa variabel terhadap satu buah variabel dan dikarenakan dalam penelitian ini memiliki 
variabel independen atau bebas lebih dari satu yang memberikan pengaruh kepada satu variabel dependen atau terikat maka pengujian hipotesis menggunakan Model Regresi Liner Berganda.

Mengingat dalam penelitan ini menggunakan variabel intervening maka dalam melakukan regresi akan dilakukan 2 (dua) kali pengujian yaitu pengujian pertama dilakukan untuk mengetahui pengaruh Investasi, Biaya Operasional dan Kinerja Keuangan terhadap Kinerja Pelayanan dengan model regresi pertama sebagai berikut :

Kinerja Pelayanan $=\alpha+ß 1$ Investasi + ß2Biaya Operasional + B3Kinerja Keuangan $+\mathrm{e}$

Sedangkan pengujian kedua dilakukan untuk mengetahui pengaruh Investasi, Biaya Operasional, Kinerja Keuangan dan Kinerja Pelayanan terhadap Pendapatan dengan model regresi keduasebagai berikut:

Pendapatan $=\alpha+$ B1Investasi + B2Biaya Operasional+ß3Kinerja Keuangan + Be4Pendapatan+ e

\section{Hasil dan Pembahasan}

Objek pada penelitian ini adalah Rumah Sakitvertikal dibawah Kementerian Kesehatan RI yang berstatus sebagai badan layanan umum sebanyak 18 (delapan belas) Rumah Sakit dari populasi sebanyak 31 (tiga puluh satu) Rumah Sakit. Penelitian dilakukan terhadap laporan keuangan yang telah dipublikasi oleh Kementerian Keuangan kemudian kinerja keuangan dan kinerja pelayanan yang telah dipublikasi melalui website masing-masing Rumah Sakit.

Data yang digunakan dalam penelitian ini adalah data sekunder yaitu dari tahun 2010 dengan tahun 2013 dan variabel penelitian ini adalah Investasi, Biaya Operasional, Kinerja Keuangan dan Kinerja Pelayanan sebagai variabel bebas dan Pendapatan sebagai variabel terikat.

\section{Analisis Deskriptif}

Berdasarkan hasil analisis deskriptif bahwa nilai minimum dan maksimum pada variabel investasi dan biaya operasional memperlihatkan adanya kenaikan setiap tahunnya dan standar deviasi yang besar, hal ini membuktikan bahwa nilai investasi dan biaya operasional Rumah Sakit Badan Layanan Umum sangat bervariatif dan adanya perbedaan yang cukup besar dari setiap investasi dan biaya operasional yang dimiliki oleh masing-masing Rumah Sakit atau dengan kata lain penyebaran nilai investasi dan biaya operasional tidak merata.
Kemudian nilai minimum dan maksimum pada variabel kinerja keuangan dan kinerja pelayanan juga memperlihatkan adanya kenaikan setiap tahunnya dan standar deviasi yang besar, hal ini membuktikan penilaian kinerja keuangan dan kinerja pelayanan sangat bervariatif dan adanya perbedaan yang cukup besar dari setiap Rumah Sakit atau dengan kata lain penyebaran hasil penilaian kinerja keuangan dan kinerja pelayanan tidak merata, begitu juga dengan variabel pendapatan mengalami penyebaran yang tidak merata.

\section{Uji Normalitas}

Berdasarkan hasil Uji $r$ menunjukkan nilai hasil signifikansi (Asym.Siq) sebesar 0,200 > 0,05 berarti dapat disimpulkan data penelitian ini berdistribusi normal.

\section{Uji Multikolonieritas}

Hasil uji multikolonieritas menunjukkan bahwa variabel independen mempunyai nilai VIF dibawah $10 \%$ sedangkan hasil tolerance tidak mempunyai nilai dibawah $10 \%$. maka dapat disimpulkan bahwa model regresi yang digunakan tidak ada multikolinearitas.

\section{Uji Heteroskedastisitas}

Hasil uji heteroskedastisitas untuk variabel independen semua diatas 0,05 hal ini menunjukkan tidak terjadi heteroskedasitas.

\section{Uji Autokorelasi}

Hasil uji Durbin-Watson menunjukkan tidak terdapat autokorelasi positif dan negatif maka dapat disimpulkan bahwa dalam model regresi linear tidak terdapat autokorelasi.

Pengaruh Investasi, Biaya Operasional dan Kinerja Keuangan terhadap Kinerja Pelayanan

Pengujian pengaruh Investasi (INV), Biaya Operasional (BO) dan Kinerja Keuangan (KU) terhadap Kinerja Pelayanan menggunakan model regeresi pertama yang memberikan hasil seperti dalam tabel 2.

Tabel 2 Hasil Pengujian Model Regresi Pertama

\begin{tabular}{lccrc}
\hline Keterangan & B & $\begin{array}{c}\text { Std. } \\
\text { Error }\end{array}$ & t-hitung & Sig. \\
\hline (INV) & 0.005 & 0.005 & 0.986 & 0,328 \\
$(\mathrm{BO})$ & -0.004 & 0.012 & -0.332 & 0.741 \\
& & & & \\
$(\mathrm{KU})$ & 3.236 & 0.408 & 7.923 & 0.000 \\
\hline
\end{tabular}




\begin{tabular}{lrr}
\hline Constant & -7.838 & 4.026 \\
R-Square & 0.618 \\
Adjusted & 0.599 \\
R-Square & \\
F-hitung & 32.859 \\
Sig. F & 0.000 \\
\hline
\end{tabular}

Nilai R Square sebesar 0,618 hal ini menunjukkan bahwa sumbangan atau kontribusi pengaruh Investasi, Biaya Operasioanl dan Kinerja Keuangan terhadap Kinerja Pelayanan adalah sebesar $61,8 \%$ sementara sisanya sebesar $38,2 \%$ merupakan kontribusi dari variabel-variabel lain yang tidak dimasukkan dalam penelitian ini.

Berdasarkan niai $\mathrm{F}$ hitung diperoleh nilai sebesar 32,859 yang lebih besar dari $\mathrm{F}$ tabel yaitu sebesar 2,75 maka dapat disimpulkan bahwa secara simultan variabel independen memberikan pengaruh terhadap variabel dependen. Nilai probabilitas (signifikansi) Uji F sebesar 0,000 <0,05 artinya lebih kecil dari nilai signifikansi yang digunakan dalam model ini, sehingga model yang digunakan dalam penelitian ini adalah baik (fit )dan terdapat variabel yang memiliki pengaruh signifikan, kemudian pengujian hipotesis model regresi ke pertama beradasarkan tabel 2 dengan menggunakan uji t menunjukan hasil secara parsial

a. Variabel Investasi memiliki $\mathrm{t}$ hitung $0.986<\mathrm{t}$ tabel 2,000 dengan nilai Sig sebesar 0,328 lebih dari 0,05 hal ini berarti menolak $\mathrm{H}_{1}$ sehingga dapat disimpulkan Investasi Rumah Sakit BLU tidak berpengaruh terhadap Kinerja Pelayanan.

b. Variabel Biaya Operasional memiliki t hitung $0,332<\mathrm{t}$ tabel 2,000 dengan nilai Sig sebesar 0,741 lebih dari 0,05 hal ini berarti menolak $\mathrm{H}_{2}$ sehingga dapat disimpulkan Biaya Operasional Rumah Sakit BLU tidak berpengaruh terhadap Kinerja Pelayanan.

c. Variabel Kinerja Keuangan memiliki t hitung 7,923 > t tabel 2,000 dengan nilai Sig sebesar 0,000 kurang dari 0,05 hal ini berarti menerima $\mathrm{H}_{3}$ sehingga dapat disimpulkanKinerja Keuangan Rumah Sakit BLU berpengaruh signifikan terhadap Kinerja Pelayanan.

Pengujian hipotesis model regresi pertama menghasilkan persamaan : Kinerja Pelayanan = $7,838+0,005 \times 1-0,004 \times 2+3,236$ X3
Pembahasan setiap variabel dari hasil pengujian hipotesis model regresi pertama adalah sebagai berikut :

\section{Pengaruh Investasi terhadap Kinerja Pelayanan}

Hasil pengujian yang menunjukkan Investasi tidak berpengaruh terhadap Kinerja Pelayanan dapat diartikan bahwa beberapa investasi yang rata-rata memiliki masa manfaat lebih dari dua belas bulan membutuhkan waktu yang cukup lama untuk memberikan pengaruh langsung terhadap peningkatan kinerja pelayanan,kegiatan investasi tetap dibutuhkan untuk peningkatan pelayanan hal ini sesuai dengan amanat Undang-Undang Nomor 44 Tahun 2009 Tentang Rumah Sakit pada pasal 4 menjelaskan bahwa Rumah Sakit mempunyai tugas memberikan pelayanan kesehatan perorangan secara paripurna.

\section{Pengaruh Biaya Operasional terhadap Kinerja Pelayanan}

Hasil pengujian yang menunjukkan Biaya Operasonal tidak berpengaruh terhadap Kinerja Pelayanandiduga bahwa biaya operasional bukan menjadi faktor utama dalam memberikan pengaruh peningkatan kinerja pelayanan atau masih perlu ada pemisahan secara rinci terhadap biaya-biaya yang dapat mempengaruhi kinerja pelayanan.

\section{Pengaruh Kinerja Keuangan terhadap Kinerja Pelayanan}

Hasil pengujian yang menunjukkan Kinerja Keuangan berpengaruh signifikan terhadap Kinerja Pelayanan dapat diartikan bahwaRumah Sakit untuk dapat meningkatkan kinerja pelayanan salah satunya adalah dengan melakukan pengelolaan keuangan dengan baik karena dalam pengelolaan kinerja keuangan ada sasaran, ada batasan yang harus dipatuhi dan standar yang sudah ditentukan.

\section{Pengaruh Investasi, Biaya Operasional, Kinerja Keuangan dan Kinerja Pelayanan terhadap Pendapatan}

Pengujian pengaruh Investasi (INV), Biaya Operasional (BO), Kinerja Keuangan (KU) dan Kinerja Pelayanan (KP) terhadap Pendapatan menggunakan model regeresi kedua yang memberikan hasil seperti dalam tabel 3 .

Tabel 3Hasil PengujianModel Regresi Kedua 


\begin{tabular}{lrrrr}
\hline Keterangan & B & $\begin{array}{c}\text { Std. } \\
\text { Error }\end{array}$ & $\begin{array}{c}\text { t- } \\
\text { hitung }\end{array}$ & Sig. \\
\hline (INV) & -0.024 & 0.013 & -1.878 & 0.065 \\
(BO) & 0.805 & 0.030 & 27.090 & 0.000 \\
$(\mathrm{KU})$ & -0.674 & 1.480 & -0.455 & 0.650 \\
(KP) & 0.925 & 0.326 & 2.841 & 0.006 \\
Constant & -32.89 & 10.555 & & \\
R-Square & 0.967 & & & \\
Adjusted & 0.965 & & & \\
R-Square & & & & \\
F-hitung & 440.110 & & & \\
Sig. F & 0.000 & & &
\end{tabular}

Nilai R Squaresebesar 0,967 hal ini menunjukkan bahwa sumbangan atau kontribusi pengaruh Investasi, Biaya Operasioanl, Kinerja Keuangan dan Kinerja Pelayanan terhadap Pendapatan adalah sebesar 96,7\% sementara sisanya sebesar 3,3\% merupakan kontribusi dari variabel-variabel lain yang tidak dimasukkan dalam penelitian ini.

Berdasarkan nilai $\mathrm{F}$ hitung diperoleh nilai sebesar 440,110 yang lebih besar dari $F$ tabel yaitu sebesar 2,52 maka dapat disimpulkan bahwa keseluruhan variabel independen memberikan pengaruh terhadap variabel depeden kemudian pengujian hipotesis model regresi kedua berdasarkan tabel 3 dengan menggunakan uji $t$ menunjukkan hasil :

a. Variabel Investasi memiliki $t$ hitung $-1,878<t$ tabel 2,000 dengan nilai Sig sebesar 0,065 lebih dari 0,05 hal ini berarti menolak $\mathrm{H}_{4}$ sehingga dapat disimpulkan Investasi Rumah Sakit BLU tidak berpengaruh terhadap Pendapatan.

b. Variabel Biaya Operasional memiliki t hitung $27,090>t$ tabel 2,000 dengan nilai Sig sebesar 0,000 kurang dari 0,05 hal ini berarti menerima $\mathrm{H}_{5}$ sehingga dapat disimpulkan Biaya Operasional Rumah Sakit BLU berpengaruh signifikan terhadap Pendapatan.

c. Variabel Kinerja Keuangan memiliki t hitung $0,455<t$ tabel 2,000 dengan nilai Sig sebesar 0,650 lebih dari 0,05 hal ini berarti menolak $\mathrm{H}_{6}$ sehingga dapat disimpulkan Kinerja Keuangan Rumah Sakit BLU tidak berpengaruh terhadap Pendapatan.

d. Variabel Biaya Kinerja Pelayanan thitung 2,841 $>\mathrm{t}$ tabel 2,000 dengan nilai Sig sebesar 0,006 kurang dari 0,05 hal ini berarti menerima $\mathrm{H}_{7}$ sehingga dapat disimpulkan Kinerja Pelayanan Rumah Sakit BLU berpengaruh signifikan terhadap Pendapatan.
Pengujian hipotesis model regresi kedua menghasilkan persamaan :Pendapatan $=-32,895-$ 0,024 X1 + 0,805 X2 - 0,674 X3 + 0,925Y

Pembahasan setiap variabel dari hasil pengujian hipotesis model regresi kedua adalah sebagai berikut :

\section{Pengaruh Investasi terhadap Pendapatan}

Hasil pengujian yang menunjukkan Investasitidak berpengaruh terhadap Pendapatan hal ini dapat diartikan bahwa sebagaian besar investasi yang dimiliki Rumah Sakit memiliki masa manfaat lebih dari dua belas bulan dan diduga sebagaian besar membutuhkan waktu yang cukup lama untuk memberikan pengaruh langsung terhadap peningkatan pendapatan.

Hasil pengujian ini bertentangan dengan hasil penelitian yang dilakukan oleh Zaenab (2013) yang menyatakan bahwa peningkatan pendapatan disalah satu Rumah Sakit pemerintah di Surabaya dipengaruhi oleh empat variabelsalah satunya yaitu investasi.

\section{Pengaruh Biaya Operasional terhadap Pendapatan}

Hasil pengujian yang menunjukkan Biaya Operasional berpengaruh signifikan terhadap Pendapatan hal ini dapat diartikan bahwa biaya operasional yang dikeluarkan oleh Rumah Sakit sudah digunakan untuk mendukung peningkatan pendapatan, hasil mendukung penelitian yang dilakukan oleh Permana (2015)memberikan hasil bahwa Biaya Operasional berpengaruhpositif dan signifikan terhadap Pendapatan.

\section{Pengaruh Kinerja Keuangan terhadap Pendapatan}

Hasil pengujian yang menunjukkan Kinerja Keuangan tidak berpengaruh terhadap Pendapatan, diduga bahwa kinerja keuangan secara keseluruhan bukan variabel yang dapat memberikan pengaruh terhadap pendapatan walaupun secara simultan dalam penelitiannya Supriyanto (2018) dan Supriyanto (2015) Kinerja Keuangan berpengaruh signifikan terhadap Pendapatan sehingga masih perlu ada pemisahan secara rinci terhadap kinerja keuangan yang dapat mempengaruhi pendapatan.

\section{Pengaruh Kinerja Pelayanan terhadap Pendapatan}

Hasil pengujian yang menunjukkan Kinerja Pelayanan berpengaruh signifikan terhadap Pendapatan,tentunya hasil pengujian yang 
diinginkan oleh manajemen Rumah Sakit sehingga dapat memotivasi Rumah Sakit untuk terus meningkatkan pelayanannya dan hasil ini juga mendukung penelitian yang telah dilakukan oleh Paki (2016) yang menyatakan adanya pengaruh positif dan signifikan dari variabel kualitas pelayanan terhadap income Rumah Sakit.

\section{Pengaruh Investasi, Biaya Operasional, Kinerja Keuangan terhadap Pendapatan melalui Kinerja Pelayanan}

Pada pengujian hipotesis ini menggunakan analisis jalur yang menggambarkan besaran pengaruh dari masing-masing variabel khususnya bagaimana pengaruh langsung dan tidak langsung dari investasi, biaya operasional dan kinerja keuangan terhadap pendapatan, berikut penjelasannya :

a. Berdasarkan hasil perhitungan analisis jalur diketahui nilai pengaruh langsung investasi terhadap pendapatan sebesar -0,058 lebih kecil dibandingkan nilai pengaruh tidak langsung sebesar 0,011016 $(0,102 \times 0,108)$ hasil ini berarti menolak $\mathrm{H}_{8}$ sehingga dapat disimpulkan bahwa Investasi Rumah Sakit BLU melalui Kinerja Pelayananberpengaruh signifikan terhadap Pendapatan.

b. Berdasarkan perhitungan analisis jalur dapat diketahui pengaruh langsung biaya operasional terhadap pendapatan sebesar 0,973 lebih besar dibandingkan nilai pengaruh tidak langsung sebesar- $0,00432(-0,040 \times 0,108)$ hasil ini berarti menolak $\mathrm{H}_{9}$ sehingga dapat disimpulkan bahwa Biaya Operasional Rumah Sakit BLU melalui Kinerja Pelayanan tidak berpengaruh terhadap Pendapatan.

c. Berdasarkan hasil perhitungan analisis jalur dapat diketahui pengaruh langsung sebesar 0,019 lebih kecil dibandingkan nilai pengaruh tidak langsung sebesar $0,0866(0,802 \times 0,108)$ hasil ini berarti menerima $\mathrm{H}_{10}$ sehingga dapat disimpulkan bahwa Kinerja Keuangan Rumah Sakit BLU melalui Kinerja Pelayanan berpengaruh signifikan terhadap Pendapatan.

\section{Gambar 2 Analisis Jalur}

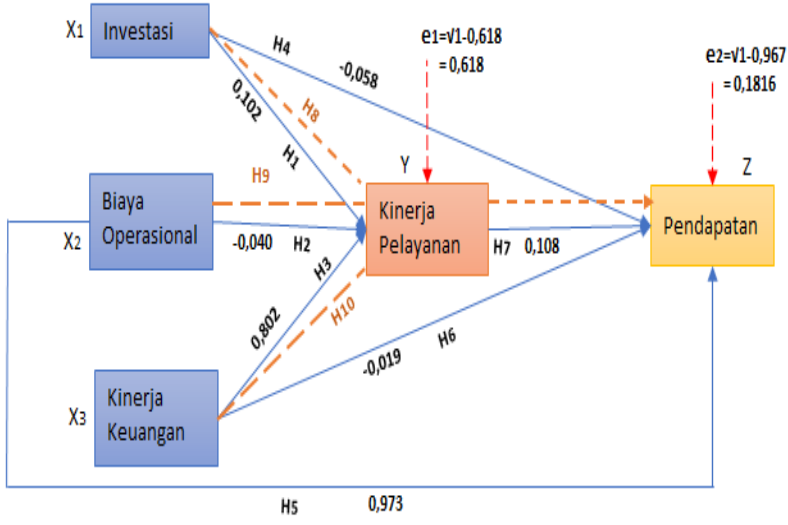

\section{Kesimpulan, Keterbatasan dan Saran}

Berdasarkan hasil pengujian hipotesis dengan model regresi pertama dan kedua serta hasil perhitungan analisis jalur dapat disimpulkan, yaitu Investasi tidak berpengaruh terhadap Kinerja Pelayanandan berdasarkan analisis jalur memperlihatkan bahwa Investasi mempunyai pengaruh positif terhadap Kinerja Pelayanan maka dari dua kondisi tersebut dapat diartikan bahwa pertumbuhan investasi dalam bentuk aset tetap di beberapa Rumah Sakit BLU belum memberikan dampak signifikan terhadap peningkatan kinerja pelayanan atau Investasi belum menjadi variabel utama dalam mendorong peningkatan kinerja pelayanan tetapi hal ini perlu dilakukan penelitian lebih lanjut untuk menyempurnakan hasil penelitian saat ini. Biaya Operasional tidak berpengaruh terhadap Kinerja Pelayanan dan berdasarkan analisis jalur memperlihatkan bahwa Biaya Operasional mempunyai pengaruh negatif terhadap Kinerja Pelayanan maka dari dua kondisi tersebut dapat diartikan bahwameningkatnya biaya operasional yang dikeluarkan oleh beberapa Rumah Sakit BLU diikuti dengan menurunya kinerja pelayanan, hal ini mungkin dapat disebabkan :

a. Biaya operasional belum sepenuhnya mengarah kepada peningkatan kinerja pelayanan mungkin hanya mengarah kepada pemeliharaan atau perbaikan, pembayaran rutin kepada pegawai.

b. Belum sepenuhnya mengarah untuk pemberian penghargaan kepada pegawai, pelatihanpelatihan untuk meningkatkan kepuasan pasien dan biaya untuk pengawasan terhadap pencapaian target kinerja pelayanan, dan

c. Biaya operasional dalam penelitian ini bukan variabel yang memberikan pengaruh langsung terhadap peningkatan kinerja pelayanan tetapi harus melalui variabel lain. 
Tentunya tiga hal ini perlu dilakukan penelitian lebih lanjut untuk menyempurnakan penelitian saat ini, yaitu Kinerja Keuangan berpengaruh signifikan terhadap Kinerja Pelayanan dan berdasarkan analisis jalur memperlihatkan Kinerja Keuangan mempunyai pengaruh positif terhadap Kinerja Pelayanan maka dari dua kondisi tersebut dapat diartikan bahwa naiknya kinerja keuangan akan diikuti meningkatnya kinerja pelayanan, hal ini dapat disebabkan diantaranya oleh :

a. Adanya pengelolaan keuangan yang baik, yaitu pembiayaan yang tepat sesuai dengan yang dibutuhkan, dan

b. Pengelolaan aset yang benar akan memberikan pengaruh terhadap kinerja pelayanan.

Investasi tidak berpengaruh terhadap Pendapatan dan berdasarkan analisis jalur memperlihatkan pengaruh langsung Investasi mempunyai pengaruh negatif terhadap Pendapatan maka dari dua kondisi tersebut dapat diartikan bahwa penurunan investasi dalam bentuk aset tetap di beberapa Rumah Sakit BLU diikuti peningkatan pendapatan dan pengaruh tidak langsung investasi melalui kinerja pelayanan mempunyai pengaruh signifikan terhadap pendapatan,beberapa hal yang menyebabkan kondisi-kondisi diatas, yaitu Investasi dilakukan kepada aset tetap yang membutuhkan waktu lama untuk bisa dikonversi menjadi pendapatan (turn over fixed asset), Investasi yang dilakukan belum mendukung secara langsung peningkatan pendapatan atau dalam penelitian ini, investasi bukan variabel yang memberikan pengaruh langsung terhadap peningkatan pendapatan tetapi harus melalui variabel lain.

Tentunya ketiga hal tersebut diatas perlu diuji kembali untuk dapat menyempurnakan penelitian saat ini, yaitu Biaya Operasional mempunyai pengaruh signifikan terhadap Pendapatan dan berdasarkan analisis jalur memperlihatkan bahwa pengaruh langsung Biaya Operasional mempunyai pengaruh positif terhadap Pendapatan maka dari kedua kondisi tersebut dapat diartikan bahwa naiknya biaya operasionaldiikuti peningkatan pendapatan dan pengaruh tidak langsung Biaya Operasional melalui kinerja pelayanan tidak mempunyai pengaruh terhadap Pendapatan, hal ini mungkin dapat disebabkan diantaranya olehbeberapa Rumah Sakit telah memberikan biaya kepada alatalat dan SDM dilayanan kesehatan yangmemberikan pengaruh langsung terhadap pendapatan; Kinerja Keuangan tidak berpengaruh terhadap Pendapatan dan berdasarkan analisis jalur memperlihatkan bahwa pengaruh langsung Kinerja Keuangan mempunyai pengaruh negatif terhadap Pendapatan dan dari kedua kondisi tersebut dapat diartikan bahwa setiap penurunan Kinerja Keuangan diikuti naiknya Pendapatan dan pengaruh tidak langsung Kinerja Keuangan melalui Kinerja Pelayanan mempunyai pengaruh signifikan terhadap Pendapatan, yang mungkin menjadi penyebab dari beberapa kondisi diatas diantaranya oleh Kinerja Keuangan bukan variabel yang memberikan pengaruh langsung terhadap Pendapatan tetapi harus melalui variabel lainnya; Kinerja Pelayanan berpengaruh signifikan terhadap Pendapatan dan berdasarkan analisis jalur memperlihatkan bahwa secara pengaruh langsung Kinerja Pelayanan mempunyai pengaruh positif terhadap Pendapatan dan dari kedua kondisi tersebut dapat diartikan bahwa setiap kenaikan Kinerja Pelayanan diikuti dengan peningkatan Pendapatan, hal ini mungkin dapat disebabkan diantaranya oleh pemberian pelayanan yang memuaskan kepada pasien akan memberikan pengaruh terhadap jumlah kunjungan dan akan mempengaruhi pendapatan Rumah Sakit.

Secara keseluruhan hasil penelitian ini menunjukan bahwa Rumah Sakit membutuhkan pemilihan investasi yang lebih tepat, Rumah Sakit meningkatkan anggaran untuk biaya yang berkaitan dengan peningkatan kinerja pelayanan, Rumah Sakitsudah melakukan pengelolaan kinerja keuangan dengan baik khususnya pengaruh kinerja keuangan melalui kinerja pelayanan terhadap pendapatan, serta diperlukannya pengembangan terhadap variabel independen untuk menyempurnakan penelitian saat ini.

Penelitian ini memiliki beberapa keterbatasan yang dapat memengaruhi hasil penelitian. Keterbatasan dalam penelitian ini antara lain Rumah Sakit BLUyang menjadi sampel pada penelitian ini hanya berjumlah 18 Rumah Sakit dari 31 Rumah Sakit BLU yang datanya dipublikasi oleh Kementerian Keuangandan dari masing-masing Rumah Sakit, hal inidikarenakan terdapat beberapadata yang tidak memenuhi kriteria sampel yang telah ditentukan dalam penelitian ini, sehingga memperkecil jumlah sampel penelitian yang digunakan. Karena keterbatasan waktu dan data yang diperoleh untuk penelitiaan maka uji hipotesis model 1 hanya menggunakan tiga variabel independen saja, yaitu Investasi, Biaya Operasional dan Kinerja Keuangandan masih ada variabel lainnya yang 
dapat mempengaruhi kinerja pelayanan seperti Kualitas Jasa diantaranya tangibility, responsiveness, reliability, security, courtesy dan personal attention.Karena keterbatasan waktu dan data yang diperoleh untuk penelitian maka analisis model 2 hanya menggunakan 4 variabel independen saja, yaitu Investasi, Biaya Operasional, Kinerja Keuangan dan Kinerja Pelayanan sementara masih ada variabel lain yang dapat mempengaruhi pendapatan diantaranya biaya-biaya yang berkaitan dengan pelayanan yaitu biaya pemeliharaan alat medik, biaya pembinaan tenaga kesehatan, pemberian kompensasi kepada tenaga kesehatan dan investasi yang dikhususkan kepada alat-alat medik.

\section{Daftar Referensi}

Anggara, S. (2016). Administrasi keuangan negara.

Fitriani, S. (2014). Pengaruh Kualitas Pelayanan Terhadap Loyalitas Melalui Kepuasan Pasien Pengguna BPJS Di Rawat Inap RSUD Dr. Moewardi (Doctoral dissertation, Universitas Muhammadiyah Surakarta).

Hamidu, N. P. (2013). Pengaruh kinerja keuangan terhadap pertumbuhan laba pada perbankan di BEI. Jurnal EMBA: Jurnal Riset Ekonomi, Manajemen, Bisnis dan Akuntansi, 1(3).

Handayani, S. B., \& Iriyanto, S. (2010). Pengaruh kualitas pelayanan dan tarif terhadap kepuasan serta implikasinya terhadap minat beli pasien rawat inap pada Rumah Sakit Roemani Muhammadiyah Semarang. Jurnal stiedharmaputra, 3(2), 1.

Istiara, F. F. (2015). Pengaruh Perputaran Aktiva Tetap Terhadap Profitabilitas Pada (Pmn) Pusat Mata Nasional Rumah Sakit Mata Cicendo Bandung Periode 20092013 (Doctoral dissertation, Universitas Widyatama).

Nurpitasari, N., Paramita, P. D., \& Pranaditya, A. (2018). Pengaruh Rasio Likuiditas, Rasio Solvabilitas Dan Rasio Activity Terhadap Kinerja Keuangan Yang Mempengaruhi Laba Perusahaan Pt Dong Bang Indo Tahun 2013-2016. Journal Of Accounting, 4(4).

Pakki, T. R. (2016). Pengaruh Kualitas Pelayanan Terhadap Income yang dimoderasi oleh LOS (Length Of Stay) di RS. Paru Dr. HA Rotinsulu Bandung (Doctoral dissertation,
UNPAS).

Permana, Y. (2015). Pengaruh Biaya Operasional terhadap Pendapatan (Studi pada Hotel Banjarmasin International)(Doctoral dissertation, Fakultas Ekonomi Unpas).

Ririn, T., Prihatni, R., \& Murdayanti, Y. (2014). Pengaruh Belanja Modal, Investasi, Dan Produk Domestik Regional Bruto Terhadap Pendapatan Asli Daerah. Jurnal Ilmiah Wahana Akuntansi, 9(1), 36-55.

Rosmalia, J., Iskandar, R., \& Fitriadi, F. (2014). Pengaruh Investasi Dan Tenaga Kerja Terhadap Produk Domestik Regional Bruto (Pdrb) Dan Pendapatan Asli Daerah (Pad) Kota Balikpapan. Journal of Innovation in Business and Economics, 5(2), 159-172.

Safitri, H. M. (2015). Analisis Pengendalian Intern Atas Pelaksanaan Prosedur Persediaan Obat-obatan pada Rumah Sakit PHC Surabaya. EQUITY, 1(2).

Subiyanto, I., \& Halim, A. (2008). Analisis investasi: belanja modal: sektor publikpemerintah daerah. Unit Penerbitan dan Percetakan, Sekolah Tinggi Ilmu Manajemen, Yayasan Keluarga Pahlawan Negara (UPP STIM YKPN).

Supriyanto, S. (2018). Pengaruh Kinerja Keuangan Terhadap Pendapatan Saham Perbankan Di Bursa Efek Indonesia. Jurnal Bis-A: Jurnal Bisnis Administrasi, 2(1), 3953.

Supriyanto, S., \& Lestari, W. (2015). Analisis Kinerja Keuangan Dengan Menggunakan Metode Economic Value Added Pada PT. Bank Mandiri (Persero), Tbk. Jurnal Bis-A: Jurnal Bisnis Administrasi, 4(1), 53-61.

Suyanto, R. dkk, (2018). Manajemen Keuangan Rumah Sakit. Diterbitkan dan Dicetak PT. Refika Aditama, Cetakan Kesatu: Maret 2018 